\title{
Large Plasmids in Different Rhizobium Species
}

\author{
By M. P. NUTI,* A. M. LEDEBOER, A. A. LEPIDI* AND \\ R. A. SCHILPEROORT \\ Department of Biochemistry, State University of Leiden, Wassenaarseweg 64, \\ Leiden, The Netherlands
}

(Received I I October 1976; revised 3 December 1976)

SUMMARY

Large plasmids were detected in Rhizobium species by sedimentation analysis of lysates on alkaline sucrose gradients and by dye buoyant density centrifugation. Mitomycin C treatment did not increase the amount of plasmid DNA in the bacteria. Renaturation kinetics were used to confirm that these large DNA molecules had the molecular complexity of plasmids and to estimate their molecular weights. These ranged from $0.7 \times 10^{8}$ to $4.0 \times 10^{8}$ daltons. The maximum yield of isolated plasmid DNA relative to chromosomal DNA was $3.8 \%$.

\section{INTRODUCTION}

The Gram negative bacterium Rhizobium can form root nodules in a complex symbiosis with legumes (Dixon \& Cannon, 1975; Dilworth, I969). The triggers for the initiation of this symbiosis are still unknown (Libbenga \& Bogers, I974; Brill, I975). Possibly plasmid genes are involved in its establishment since rhizobia treated with acridine dyes or chemicals known to eliminate extrachromosomal DNA lose their ability to form nodules (Higashi, 1967; Dunican \& Cannon, 197I ; Zurkowski, Hoffman \& Lorkiewicz, I973). The isolation of plasmid DNA from rhizobia by dye buoyant density centrifugation of 'cleared' lysates has recently been reported (Tshitenge et al., 1975; Luyindula et al., 1975; Dunican, O'Gara \& Tierney, 1975); but only Tshitenge et al. (1975) gave an estimation of its molecular weight (about $28 \times 10^{6}$ daltons). No findings correlating nodule formation with the presence of plasmid have yet been published. It has been suggested that nitrogen fixation genes might be plasmid borne in Rhizobium (Dunican \& Tierny, 1974), although no additional evidence to support this idea has been reported.

In this paper, we report conditions suitable for the reproducible recovery of large plasmids from Rhizobium species, which are not detected when using 'cleared' lysates. Estimates of the molecular weight of the plasmids based on renaturation kinetics data are presented and the possible significance of such large extrachromosomal DNA in Rhizobium is discussed.

METHODS

Bacterial strains and their symbiotic or biological properties are listed in Table $\mathrm{I}$.

Cultivation of bacteria. The strains of Rhizobium were maintained by weekly subculturing on slants of yeast/mannitol/agar (YMA) containing ( $\left.\mathrm{g} \mathrm{l}^{-1}\right): \mathrm{K}_{2} \mathrm{HPO}_{4}, 0 \cdot 5 ; \mathrm{MgSO}_{4} \cdot 7 \mathrm{H}_{2} \mathrm{O}$, $0.2 ; \mathrm{NaCl}, 0 . \mathrm{I}$; yeast extract (Difco), 0.4 ; mannitol, I0.0; and agar (Difco), I 5.0 ; the pH was adjusted to 6.9 before sterilization.

* Present address: Istituto di Microbiologia Agraria, Università di Pisa, Via del Borghetto 80, Pisa, Italy. 
Table I. Symbiotic and biological properties of bacterial strains

\begin{tabular}{|c|c|c|c|c|c|}
\hline \multirow[b]{2}{*}{ Species } & \multirow[b]{2}{*}{$\begin{array}{l}\text { Strain } \\
\text { no. }\end{array}$} & \multirow[b]{2}{*}{ Source } & \multicolumn{3}{|c|}{ Symbiotic properties* } \\
\hline & & & Inf & Eff & Test plant \\
\hline $\begin{array}{l}\text { Rhizobium } \\
\text { leguminosarum }\end{array}$ & 1001 & $\begin{array}{l}\text { Rothamsted } \\
\text { (Harpenden) }\end{array}$ & + & $\begin{array}{l}+ \\
+\end{array}$ & $\begin{array}{l}\text { Vicia hirsuta } \\
\text { V. faba }\end{array}$ \\
\hline R. leguminosarum & 1016 & $\begin{array}{l}\text { Rothamsted } \\
\text { (Harpenden) }\end{array}$ & $=$ & & $\begin{array}{l}\text { Vicia hirsuta } \\
\text { V. faba }\end{array}$ \\
\hline R. trifolii & 5 & $\begin{array}{l}\text { Rothamsted } \\
\text { (Harpenden) }\end{array}$ & $\begin{array}{l}+ \\
+\end{array}$ & \pm & $\begin{array}{l}\text { Trifolium pratense } \\
\text { T. parviforum }\end{array}$ \\
\hline R. trifolii & 0402 & $\begin{array}{l}\text { Rothamsted } \\
\text { (Harpenden) }\end{array}$ & - & & T.pratense \\
\hline R. japonicum & 3407 & $\begin{array}{l}\text { Rothamsted } \\
\text { (Harpenden) }\end{array}$ & + & + & Glycine max \\
\hline R. 'dolichos' & RDI & $\begin{array}{l}\text { Nodules of } \\
\text { Dolichos lab lab } \\
\text { (Afgoi, Somaliland) }\end{array}$ & + & + & Dolichos lab lab \\
\hline $\begin{array}{l}\text { Agrobacterium } \\
\text { tumefaciens }\end{array}$ & LBA60I & $\begin{array}{l}\text { Dept of Bio- } \\
\text { chemistry, Leiden, } \\
\text { Holland }\end{array}$ & $\begin{array}{l}\text { Tumo } \\
\text { on d } \\
\text { plan } \\
\text { et al. }\end{array}$ & $\begin{array}{l}\text { ming } \\
\text { donous } \\
\text { oykaas } \\
\text { ) }\end{array}$ & $\begin{array}{l}\text { Kalanchoë daigre- } \\
\text { montiana, Nicotiana } \\
\text { tabacum, Helianthus } \\
\text { annuus }\end{array}$ \\
\hline
\end{tabular}

* Inf, infectiveness, i.e. ability to form nodules; Eff, effectiveness, i.e. ability to fix nitrogen.

Liquid cultures were grown in yeast/mannitol/broth (YMB) which had the same composition as YMA without agar. Unless otherwise indicated, $25 \mathrm{ml}$ cultures were inoculated from slants and shaken at $29^{\circ} \mathrm{C}$ on a rotary shaker at $250 \mathrm{rev} . \mathrm{min}^{-1}$. All Rhizobium strains used for plasmid DNA analysis were able to nodulate the appropriate host.

Agrobacterium tumefaciens strain LBA6OI was cultured as described by Ledeboer et al. (I976) and its purity was checked as described by Hooykaas et al. (I977).

Nodulation tests. Enclosed cultures on seedling agar were carried out according to Vincent (1970). Each $R$. trifolii strain was tested on 12 plants of Trifolium pratense cv. 5I23 and $T$. parviflorum (kindly provided by Dr P. S. Nutman), each $R$. leguminosarum strain on eight Vicia faba and $V$. hirsuta, and the $R$. 'dolichos' strain on eight Dolichos lab lab. Acetylene reduction by intact plants was measured in air containing $10 \%(\mathrm{v} / \mathrm{v})$ acetylene (Planqué \& van Brussel, 1976); effectiveness for Dolichos nodules was assumed on the basis of their inner pigmentation. Gas chromatography was performed as described by Citernesi et al. (1976).

Mitomycin $C$ treatment. Mitomycin $\mathrm{C}$ was added to a final concentration of $\mathrm{I} \mu \mathrm{g} \mathrm{m}^{-1}$ to mid-exponential phase cultures in YMB at a density of about $2 \times 10^{8}$ bacteria $\mathrm{ml}^{-1}$. Bacteria were sedimented after $90 \mathrm{~s}$ as described by Pariiskaya (1973).

Labelling procedure. Rhizobia were grown in YMB to a density of $\mathrm{I} \times 10^{8}$ bacteria $\mathrm{ml}^{-1}$. To $0.9 \mathrm{ml}$ of this bacterial culture, $0 . \mathrm{I} \mathrm{mCi}\left[{ }^{3} \mathrm{H}\right]$ thymidine $\left(30 \mathrm{Ci} \mathrm{mM}^{-1}\right.$; The Radiochemical Centre, Amersham) was then added slowly and continuously by means of a peristaltic pump during a growth period of 3 to $4 \mathrm{~h}$, depending on the strain used. Bacteria were grown to a density of $4 \times 10^{8}$ to $6 \times 10^{8}$ bacteria $\mathrm{ml}^{-1}$. Deoxyadenosine was not added since it did not improve labelling efficiency. After a further $30 \mathrm{~min}$ growth without addition of $\left[{ }^{3} \mathrm{H}\right]$ thymidine, bacteria were harvested by centrifugation at $12000 \mathrm{~g}$ for $20 \mathrm{~min}$ and plasmid DNA was isolated. Agrobacterium tumefaciens was labelled as described by Ledeboer et al. (I976).

Plasmid isolation and purification. (i) Lysate preparation. Rhizobium cells were lysed as described by Ledeboer et al. (1976) with the following modifications: cells were resuspended 
in 0.45 vol. sterile TES buffer (containing $0.0 \mathrm{r} \mathrm{M}$-Tris $\mathrm{pH} 8.0,0.05 \mathrm{M}-\mathrm{NaCl}$ and $0.05 \mathrm{M}$ EDTA) and added to 0.45 vol. lysozyme $\left(400 \mu \mathrm{g} \mathrm{ml}^{-1}\right.$; eggwhite, grade I, Sigma) in TES buffer saturated with n-dodecylamine. After $30 \mathrm{~min}$ incubation on ice without stirring, 0.1 vol. I0 \% (w/v) Sarkosyl NL97 (Ciba Geigy, Switzerland) in TES was added, followed by $0 \cdot \mathrm{I}$ vol. $3 \mathrm{M}-\mathrm{NaOH}$ plus $\mathrm{I} \mathrm{M}-\mathrm{NaCl}$ in TES. This procedure always gave clear lysates within a few minutes. In some experiments, a 3 to 7 min incubation at $37^{\circ} \mathrm{C}$ with pronase (250 $\mu \mathrm{g} \mathrm{ml}^{-1}$; B grade, Calbiochem), autodigested for $\mathrm{I} \cdot 5 \mathrm{~h}$ at $37^{\circ} \mathrm{C}$ in prewarmed TES buffer, was used before addition of Sarkosyl. Alternatively, the procedure reported by Zaenen et al. (1974) was used, which gave almosi clear lysates.

(ii) Alkaline sucrose gradients. The lysate [0.2 ml prepared by the Zaenen et al. (1974) procedure or I to $3 \mathrm{ml}$ by our procedure] was sheared for $\mathrm{I} \cdot 5 \mathrm{~min}$ in a test tube (I.6 $\mathrm{cm} \mathrm{diam}$.) using a Vortex mixer at maximum speed (Vortex Genie, Wilten, Holland). Sheared lysate ( $0 . \mathrm{I}$ to $\mathrm{I} \mathrm{ml}$ ) was layered on a 5 to $20 \%$ linear sucrose gradient containing $\mathrm{I} \mathrm{M}-\mathrm{NaCl}$ and $0.3 \mathrm{M}-\mathrm{NaOH}$ in TES buffer. Autoclaved sucrose stock solutions were used. Gradients were centrifuged, unless stated otherwise, for $18 \mathrm{~min}$ at $4{ }^{\circ} \mathrm{C}$ and $37000 \mathrm{rev}$. $\min ^{-1}$ using a $\mathrm{SW}_{4} \mathrm{I}$ rotor in a Beckman Spinco LIIB preparative ultracentrifuge. Alternatively, $3 \mathrm{ml}$ lysate was layered on top of a $36 \mathrm{ml} 5$ to $20 \%$ alkaline sucrose gradient and centrifuged for $55 \mathrm{~min}$ at $4{ }^{\circ} \mathrm{C}$ and $25000 \mathrm{rev} . \mathrm{min}^{-1}$ in a SW2 $\%$ rotor. The gradients were fractionated, precipitated and radioactivity was measured as described by Ledeboer et al. (1976).

(iii) Dye buoyant density equilibrium centrifugation. Using neutral lysates, propidium di-iodide (A grade, Calbiochem) buoyant density centrifugation was performed as described by Ledeboer et al. (1976).

(iv) Alkaline large scale isolation. A combination of the alkaline large-scale isolation procedure adopted by Ledeboer et al. (1976) and of the alkaline lysis procedure of Zaenen et al. (1974) was chosen. Cultures $(250 \mathrm{ml})$ were grown to a density of $5 \times 10^{8}$ bacteria $\mathrm{ml}^{-1}$ under the same conditions as described for $25 \mathrm{ml}$ samples. The bacteria were harvested and washed with the same volume of washing mixture, then resuspended carefully in I $5 \mathrm{ml}$ lysis buffer (Zaenen et al., I974); $35 \mathrm{ml}$ lysing mixture (containing $0.8 \mathrm{M}-\mathrm{NaOH}$ and $5 \%$ Sarkosyl) were added in 3 min with slow stirring. After shearing for I min with a Vibromixer (A. G. für Chemie Apparatenbau, Switzerland), the lysate was processed as described by Ledeboer et al. (1976). Alkaline sucrose gradients (Io to $20 \%$ ) containing $\mathrm{I} \mathrm{M-NaCl}$ were run for $70 \mathrm{~min}$ at $25000 \mathrm{rev} . \mathrm{min}^{-1}$ in a SW27 rotor at $4{ }^{\circ} \mathrm{C}$.

DNA renaturation kinetics. DNA renaturation kinetics and DNA concentrations were, determined as described by Ledeboer et al. (1976).

\section{RESULTS}

\section{Lysate preparation and plasmid isolation}

The carbenicillin lysis procedure developed by Ledeboer et al. (1976), for agrobacteria was not suitable for the recovery of large plasmids from the Rhizobium species. Furthermore lysozyme/EDTA incubation followed by neutral Sarkosyl lysis was only suitable for isolating plasmid from $R$. trifolii. However, the procedure described in Methods resulted in clear lysates for all the strains studied. From these lysates, large plasmids could be isolated reproducibly in alkaline sucrose gradients, both in small (Fig. I) and large scale experiments. We also studied whether the use of pronase B or increased concentrations of lysozyme before addition of alkali was beneficial, but the isolation of large plasmids on alkaline sucrose gradients from such lysates was often unsuccessful.

Usually plasmids could only be isolated when alkaline conditions for lysis were used, 


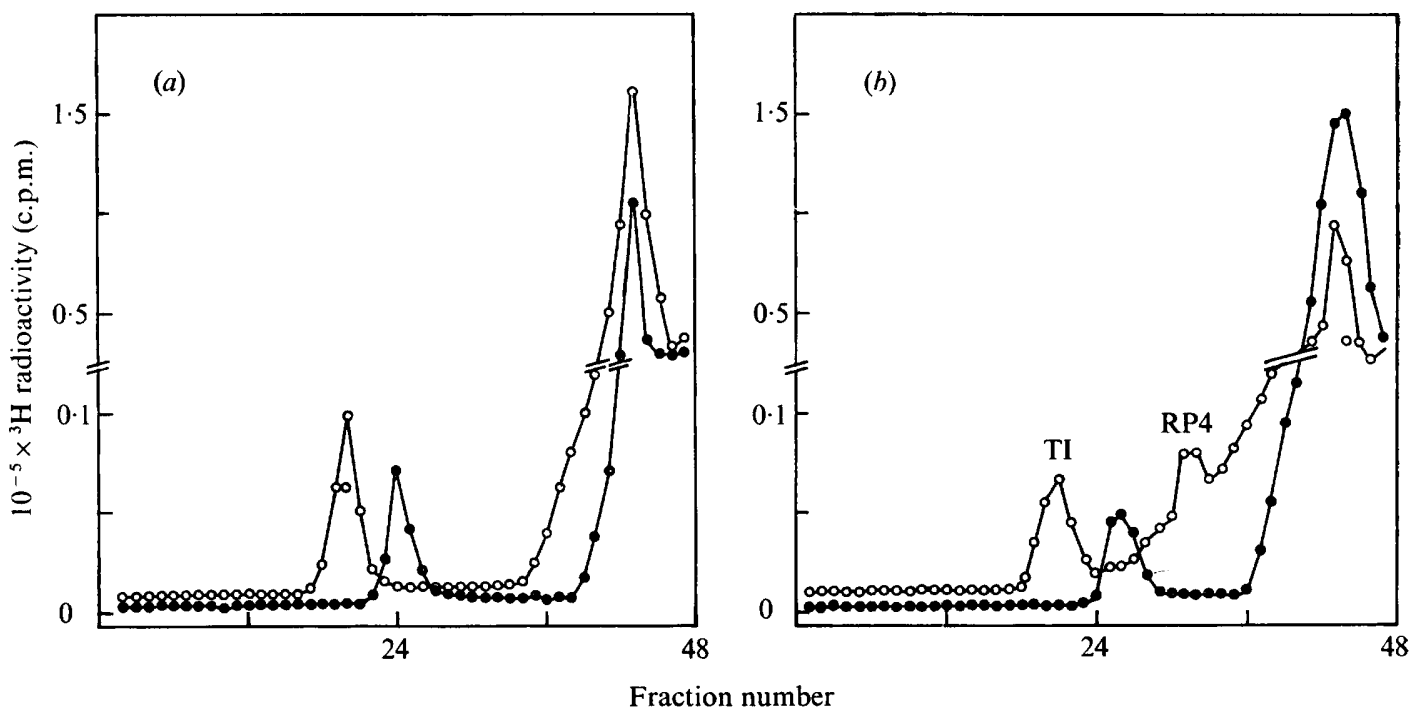

Fig. I. The isolation of Rhizobium plasmids on alkaline sucrose gradients: $(a)$ I 7 min run of sheared lysates from $R$. trifolii strain $5(O)$ and $R$. leguminosarum strain $1001(O) ;(b) 20$ min run of sheared lysates of $A$. tumefaciens LBA6OI (O), resulting in separation of the TI plasmid and RP4, and of $R$. leguminosarum strain I0I6 (O).

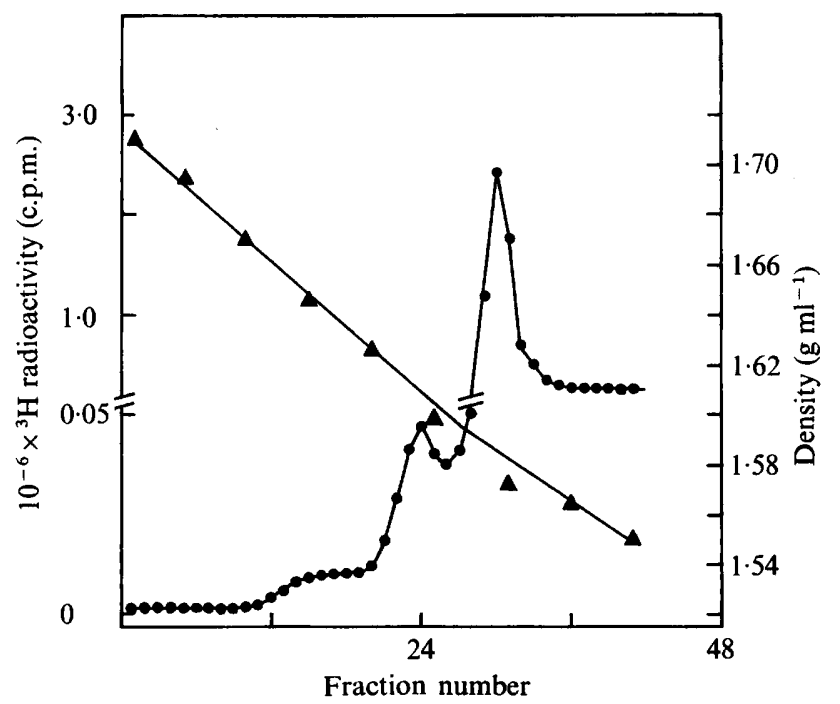

Fig. 2. $\mathrm{CsCl} /$ propidium di-iodide buoyant density profile of a neutral lysate of $\boldsymbol{R}$. trifolii strain 5 :

$0,{ }^{3} \mathbf{H}$ radioactivity; $\boldsymbol{\Delta}$, density.

though that from $R$. trifolii strain 5 could be isolated from neutral lysates by propidium di-iodide buoyant density centrifugation (Fig. 2).

A $250 \mathrm{ml}$ culture of $R$. leguminosarum strain IOOI at a concentration of $5 \times 10^{8}$ to $6 \times 10^{8}$ bacteria $\mathrm{ml}^{-1}$ yielded $9 \mu \mathrm{g}$ plasmid DNA. Assuming one plasmid copy per cell and taking into account the molecular weights determined by renaturation kinetics, the recovery is 
about $25 \%$ of the theoretical value. By renaturation kinetics the purity of the plasmid preparations was estimated to be over $90 \%$ (Ledeboer et al., 1976).

\section{Plasmid characterization}

The sedimentation profiles of clear lysates of rhizobia in alkaline sucrose gradients are shown in Fig. I. Agrobacterium tumefaciens strain LBA60I, lysed as described by Ledeboer et al. (I976), was used as an internal standard because it carries both the large $\left(\mathrm{I} \cdot \mathrm{I} \times 1 \mathrm{IO}^{8}\right.$ daltons) TI plasmid (Zaenen et al., 1974) and RP4 which has a moleculat weight of $40 \times 10^{6}$ daltons (Datta et al., I97I; O'Gara \& Dunican, I973). The large Rhizobium plasmids were invariably lost when alkaline sucrose gradients were run for longer than 22 min using a SW4I rotor in a Beckman Spinco LIIB preparative ultracentrifuge. For most strains good separation of plasmid and chromosomal DNA occurred in runs of 17 to $20 \mathrm{~min}$.

The nature of the peaks in the alkaline sucrose gradients was established by determination of the molecular complexities using renaturation kinetics (Ledeboer et al., 1976). As standards, the molecular weights of the $A$. tumefaciens TI plasmid and chromosomal DNA were used $\left[\mathrm{I} \cdot \mathrm{I} \times \mathrm{IO}^{8}\right.$ and $3.7 \times 10^{9}$ daltons respectively (Zaenen et al., I974)]. The satellite peaks in alkaline sucrose gradients appear to represent plasmid DNA (Fig. 3) and their molecular complexity was ro to 25 times lower than that of the chromosomal DNA of A. tumefaciens strain LBA6or.

The molecular weights of the Rhizobium plasmids studied were generally higher than that of the Agrobacterium TI plasmid (Table 2). The plasmid from $R$. trifolii strain 5 had the highest molecular weight, but although it also had the highest sedimentation value, the latter was not consistent with the high molecular complexity.

To determine whether the number of plasmid copies per cell could be increased, bacteria were treated with mitomycin C. No effect on copy number was observed.

\section{DISCUSSION}

Other workers (Tshitenge et al., 1975; Luyindula et al., I975; Dunican et al., 1974) using 'cleared' lysates were unable to demonstrate the presence of large plasmids in Rhizobium species. This was probably because the initial step in their preparation involved the removal of chromosomal DNA as part of a membrane complex and so large plasmids which are tightly associated with the membrane or the chromosomal DNA, such as the Agrobacterium TI plasmid (Ledeboer et al., 1976), are lost. This phenomenon has been encountered with other plasmids (Kline \& Miller, I975; Palchaudhuri \& Chakrabarty, I976). Neutral lysates were always less clear than the alkaline ones and, except for $R$. trifolii strain 5 , it was not possible to isolate the large Rhizobium plasmids using neutral conditions. To make the neutral lysates clearer we used Rhizobium grown in the presence of carbenicillin, as described for Agrobacterium (Ledeboer et al., 1976). Probably due to the much lower growth rate of rhizobia, carbenicillin did not sufficiently alter wall structure to promote lysis by lysozyme.

The presence of a very large plasmid in $R$. trifolii strain 5 is suggested by the renaturation kinetics data. The sedimentation profile (Fig. I $a$ ) shows that this plasmid is somewhat larger than that from $R$. leguminosarum IOOI, but its molecular weight is different when calculated from renaturation data. It is possible that two different plasmids of comparable molecular weight sediment at the same position. This would be consistent with the very high molecular complexity of the $R$. trifolii strain 5 plasmid. A similar discrepancy caused by the presence of two different plasmids has recently been observed for Agrobacterium strain LBA2 (A. M. Ledeboer, unpublished data). 


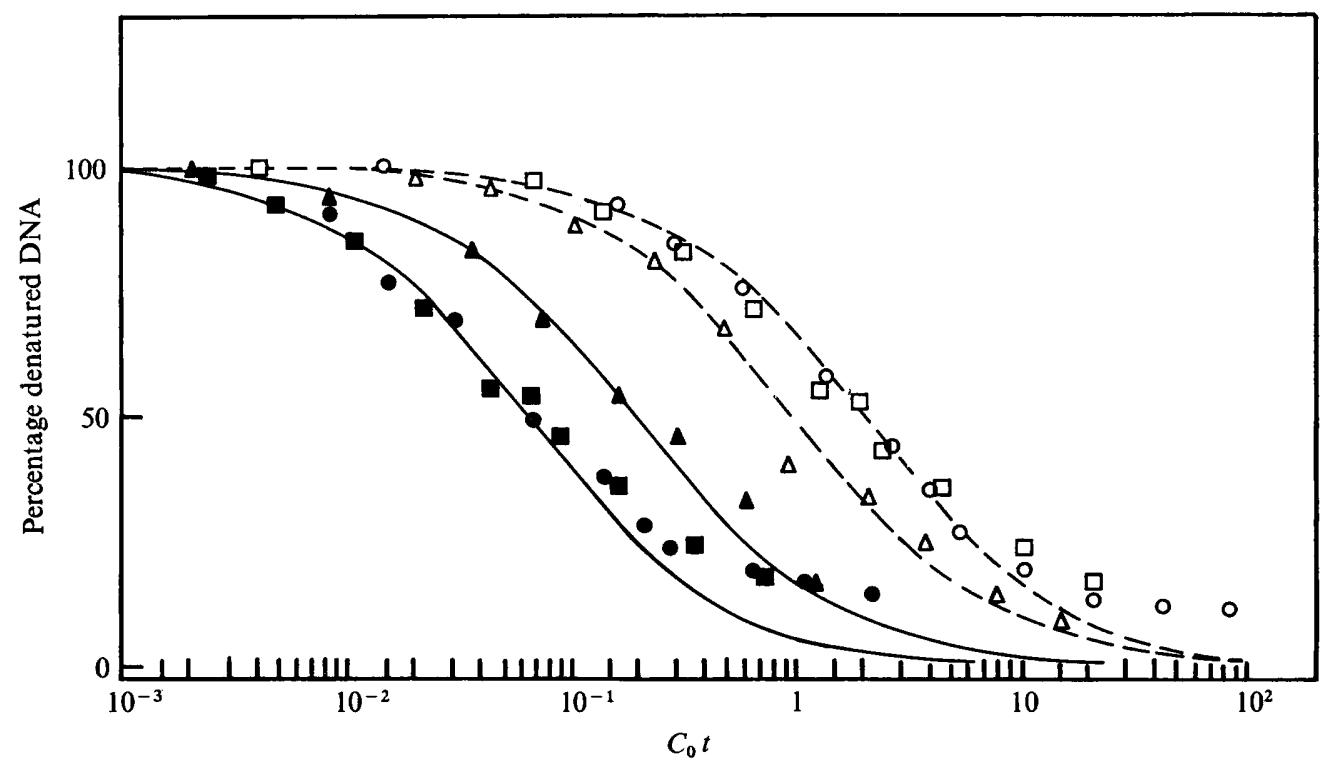

Fig. 3. $C_{0} t$ curves of plasmid and chromosomal DNA isolated from $R$. trifolii and $A$. tumefaciens: plasmid (O) and chromosomal (O) DNA from $A$. tumefaciens LBA6oI ; plasmid (A) and chromosomal $(\Delta)$ DNA from $R$. trifolii strain 5; plasmid ( $\square$ ) and chromosomal ( $\square$ ) DNA from $R$. trifolii strain 0402 . Curves have been drawn on the basis of the theoretical sigmoid curves as described by Ledeboer et al. (1976).

Table 2. Characterization of large plasmids in different Rhizobium species

\begin{tabular}{|c|c|c|c|c|c|}
\hline Species & $\begin{array}{c}\text { Strain } \\
\text { no. }\end{array}$ & $\begin{array}{l}\text { Symbiotic } \\
\text { properties* }\end{array}$ & $C_{0} t_{\underline{1}}$ & $\begin{array}{l}\text { Calculated } \\
\text { mol. wt } \\
\text { (daltons) }\end{array}$ & Yield (\%)† \\
\hline R. leguminosarum & IOOI & $\operatorname{Inf}^{+} \mathrm{Eff}^{+}$ & 0.070 & $\begin{array}{l}1.3 \times 10^{8} \\
\quad(3 \text { expts })\end{array}$ & $1.6(\max .2 \cdot 4)$ \\
\hline R. leguminosarum & I0I6 & Inf- $^{-}$ & 0.040 & $\begin{array}{c}0.7-1 \cdot 0 \times 10^{8} \\
\quad(3 \text { expts })\end{array}$ & $2 \cdot 8(\max .3 \cdot 2)$ \\
\hline R. trifolii & 5 & $\operatorname{Inf}^{+}$Eff $^{+}$ & 0.200 & $\begin{array}{c}3.5-4.0 \times 10^{8} \\
(5 \text { expts })\end{array}$ & $2 \cdot 4(\max .3 \cdot 8)$ \\
\hline R. trifolii & 0402 & Inf- $^{-}$ & 0.080 & $\begin{array}{c}1 \cdot 4 \times 10^{8} \\
(3 \text { expts })\end{array}$ & $1 \cdot 4(\max .2 \cdot 0)$ \\
\hline R. japonicum & 3407 & Inf $^{+} \mathrm{Eff}^{+}$ & - & - & $\mathrm{I} \cdot 3(\max . \mathrm{I} \cdot 8)$ \\
\hline R. 'dolichos' & RDI & $\operatorname{Inf}^{+}$Eff $^{+}$ & 0.090 & $\begin{array}{l}\mathrm{I} \cdot 6 \times 10^{8} \\
(\mathrm{I} \text { expt) }\end{array}$ & $2 \cdot 7(\max .2 \cdot 7)$ \\
\hline A. tumefaciens & LBA60I & $\begin{array}{l}\text { Tumour- } \\
\text { forming }\end{array}$ & 0.065 & $\begin{array}{l}\mathrm{r} \cdot 1 \times 10^{8} \\
\quad(6 \text { expts })\end{array}$ & $0.91(\max .1 \cdot 3)$ \\
\hline
\end{tabular}

* Sèe Table 1 .

$\dagger$ The ratio of plasmid to chromosomal DNA has been calculated according to Zaenen et al. (1974).

The four nodule-forming effective strains of Rhizobium harboured large plasmids having molecular weights in the range of $1 \cdot 3 \times 10^{8}$ to $4.0 \times 10^{8}$ daltons. The two non-infective strains carried large plasmids with lower molecular weights. These were not geneticallymarked isogenic strains and so it is not possible to draw any conclusion from these data about the involvement of plasmid genes in nodulation. However, a large plasmid controls the interaction between $A$. tumefaciens and the plant cell in crown gall formation (van Larebeke et al., 1974, 1975). It is possible that something similar occurs in nodule formation 
by Rhizobium as agrobacteria and rhizobia are taxonomically closely related (Gibbins \& Gregory, 1972; White, 1972). Nodulating effective rhizobia, able to induce tumours, have been produced by transferring the TI plasmid from Agrobacterium (Hooykaas et al., 1977). Therefore, it seems worthwhile to investigate whether the large plasmids of Rhizobium are involved in the establishment of the association between plant and bacterium.

The authors gratefully acknowledge the technical assistance of Mrs A. den Dulk-Ras and Mr G. Ooms. Professor P. S. Nutman generously provided the Rhizobium strains used in this study. The authors thank Dr J. E. Beringer for his critical reading of the manuscript. This investigation was partly supported by E.E.C. grant 044I. M.P.N. was on leave from the University of Pisa with a NATO-CNR fellowship.

\section{REFERENCES}

BRILL, W. J. (1975). Regulation and genetics of bacterial nitrogen fixation. Annual Review of Microbiology 29, I09-129.

Citernesi, U., Neglia, R., Seritti, A., Lepidi, A. A., Filippi, C., Bagnoli, G. \& Nuti, M. P. (I976). Nitrogen fixing bacteria in the gastroenteric cavity of soil animals. Soil Biology and Biochemistry (in the Press).

Datta, N., Hedges, R. W., Shaw, E. J., Sykes, R. B. \& Richmond, M. (I971). Properties of an R. factor from Pseudomonas aeruginosa. Journal of Bacteriology ro8, I $244-\mathrm{I} 249$.

Dilworth, M. J. (I969). The plant as the genetic determinant of leghaemoglobin production in the legume root nodule. Biochimica et biophysica acta $184,432-44 \mathrm{I}$.

Dixon, R. A. \& Cannon, F. C. (1975). Recent advances in the genetics of nitrogen fixation. In Symbiotic Nitrogen Fixation in Plants, pp. 3-24. Edited by P. S. Nutman. Cambridge: Cambridge University Press.

Dunican, L. K. \& CANNON, F. C. (I97I). The genetic control of symbiotic properties in Rhizobium: evidence for plasmid control. Plant and Soil, special volume 73-79.

Dunican, L. K. \& TIERNEY, A. B. (1974). Genetic transfer of nitrogen fixation from $R$. trifolii to K. aerogenes. Biochemical and Biophysical Research Communications 57, 62-72.

Dunican, L. K., O'Gara, F. \& Trerney, A. B. (1975). Plasmid control of effectiveness in Rhizobium: transfer of nitrogen-fixing genes on a plasmid from Rhizobium trifolii to Klebsiella aerogenes. In Symbiotic Nitrogen Fixation in Plants, pp. 77-90. Edited by P. S. Nutman. Cambridge: Cambridge University Press.

GibBins, A. M. \& Gregory, K. F. (1972). Relatedness among Rhizobium and Agrobacterium species determined by three methods of nucleic acid hybridization. Journal of Bacteriology III, I29-I4I.

Higashi, S. (1967). Transfer of clover infectivity of $R$. trifolii to $R$. phaseoli as mediated by an episomic factor. Journal of General and Applied Microbiology 13, 391-403.

Hooykaas, P. J. J., KlapwiJk, P. M., Nuti, M. P., Schilperoort, R. A. \& Rörsch, A. (1977). Transfer of the Agrobacterium tumefaciens TI plasmid to avirulent Agrobacteria and to Rhizobium ex planta. Journal of General Microbiology 98, 477-484.

KLINE, B. C. \& MiLleR, J. R. (I975). Detection of nonintegrated plasmid DNA in the folded chromosome of E. coli. Journal of Bacteriology I21, I65-172.

Larebeke, N. van, Engler, G., Holsters, M., van den Elsacker, S., Zaenen, I., Schilperoort, R. A. \& ScHell, J. (1974). Large plasmid in Agrobacterium tumefaciens essential for crown gall inducing ability. Nature, London 252, I69-I 70.

Larebeke, N. van, Genetello, Ch., Schell, J., Schilperoort, R. A., Hermans, A. K., Hernalsteens, J. P. \& VAN MontaGU, M. (1975). Acquisition of tumour inducing ability by nononcogenic Agrobacteria as a result of plasmid transfer. Nature, London 255, 742-743.

Ledeboer, A. M., Krol, A. J. M., Dons, J. J. M., Spier, F., Schilperoort, R. A., Zaenen, I., van LareBEKE, N. \& SCHELL, J. (1976). On the isolation of TI plasmid from A.tumefaciens. Nucleic Acids Research 3, 449-463.

LibBenga, K. R. \& Bogers, R. J. (1974). Root-nodule morphogenesis. In The Biology of Nitrogen Fixation, pp. 430-472. Edited by A. Quispel. Amsterdam: North Holland Publishing Company.

Luyindula, N., Tshitenge, G., LuRQuin, P. \& Ledoux, L. (1975). Étude des plasmides de Rhizobium japonicum. Archives internationales de physiologie et de biochimie 83, 199-200.

O'GARA, F. \& DunICAN, L. K. (1973). Transformation and physical properties of R factor RP4 transferred from Escherichia coli to Rhizobium trifolii. Journal of Bacteriology 116, $1177-1180$.

Palchaudiuri. S. \& Chakrabarty, A. (1976). Isolation of plasmid DNA from Pseudomonas putida Journal of Bacteriology 126, 410-416. 
Parisskaya, A. N. (1973). The effect of acridine orange and mitomycin $C$ on the symbiotic properties of $R$. meliloti. Mikrobiologiya 42, I19-12I.

Planqué, K. \& van Brussel, A. A. N. (1976). An improved large scale isolation procedure for bacteroids of R. leguminosarum Frank from Pisum sativum. Plant and Soil 45, 309-31 5.

Tshitenge, G., LuYindula, N., LuRQuin, P. F. \& Ledoux, L. (1975). Plasmid DNA in $R$. vigna and $R$. trifolii. Biochimica et biophysica acta 414, 357-361.

Vincent, J. M. (1970). A Manual for the Practical Study of Root-nodule Bacteria, pp. 75-82. Oxford: Blackwell Scientific Publications.

White, L. O. (1972). The taxonomy of the crown gall organism Agrobacterium tumefaciens and its relationship to Rhizobia and other Agrobacteria. Journal of General Microbiology 72, 565-574.

Zaenen, I., van Larebeke, N., Teuchy, H., van Montagu, M. \& Schell, J. (1974). Supercoiled circular DNA in crown gall inducing Agrobacterium strains. Journal of Molecular Biology 86, 109-127.

ZuRkowski, W., HofFMAN, M. \& LORKIEWICZ, Z. (I973). Effect of acriflavine and sodium dodecyl sulphate on infectiveness of $R$. trifolii. Acta microbiologia polonica, Series $A$ 5, 55-60. 